\title{
Correction to: Pro-neurogenic effect of $\beta$-asarone on RSC96 Schwann cells in vitro
}

\author{
Fuben $X u^{1,2} \cdot$ Huayu $\mathrm{Wu}^{3} \cdot$ Kun Zhang ${ }^{4,5} \cdot$ Peizhen $\mathrm{Lv}^{4,5} \cdot$ Li Zheng $^{2,4} \cdot$ Jinmin Zhao ${ }^{1,2,4,5}$ \\ Published online: 25 June 2019 \\ (C) The Society for In Vitro Biology 2019
}

Correction to: In Vitro Cell. Dev. Biol. -Animal (2016)

52:278-286

https://doi.org/10.1007/s11626-015-9980-1

In the original article there is an error in Fig. 5. The photo in row 6 days, column A2 is incorrect. Following is the corrected figure:

The online version of the original article can be found at https://doi.org/ 10.1007/s11626-015-9980-1

Li Zheng

zhengli224@163.com

$\triangle$ Jinmin Zhao

zhaojinmin@126.com

1 Guangxi Collaborative Innovation Center for Biomedicine, Guangxi Medical University, Nanning, China

2 The Medical and Scientific Research Center, Guangxi Medical University, Nanning, China

3 Department of Cell Biology \& Genetics, School of Premedical Sciences, Guangxi Medical University, Nanning, China

4 Guangxi Key Laboratory of Regenerative Medicine, Guangxi Medical University, Nanning, China

5 Department of Orthopaedics Trauma and Hand Surgery, The First Affiliated Hospital of Guangxi Medical University, Nanning, China 

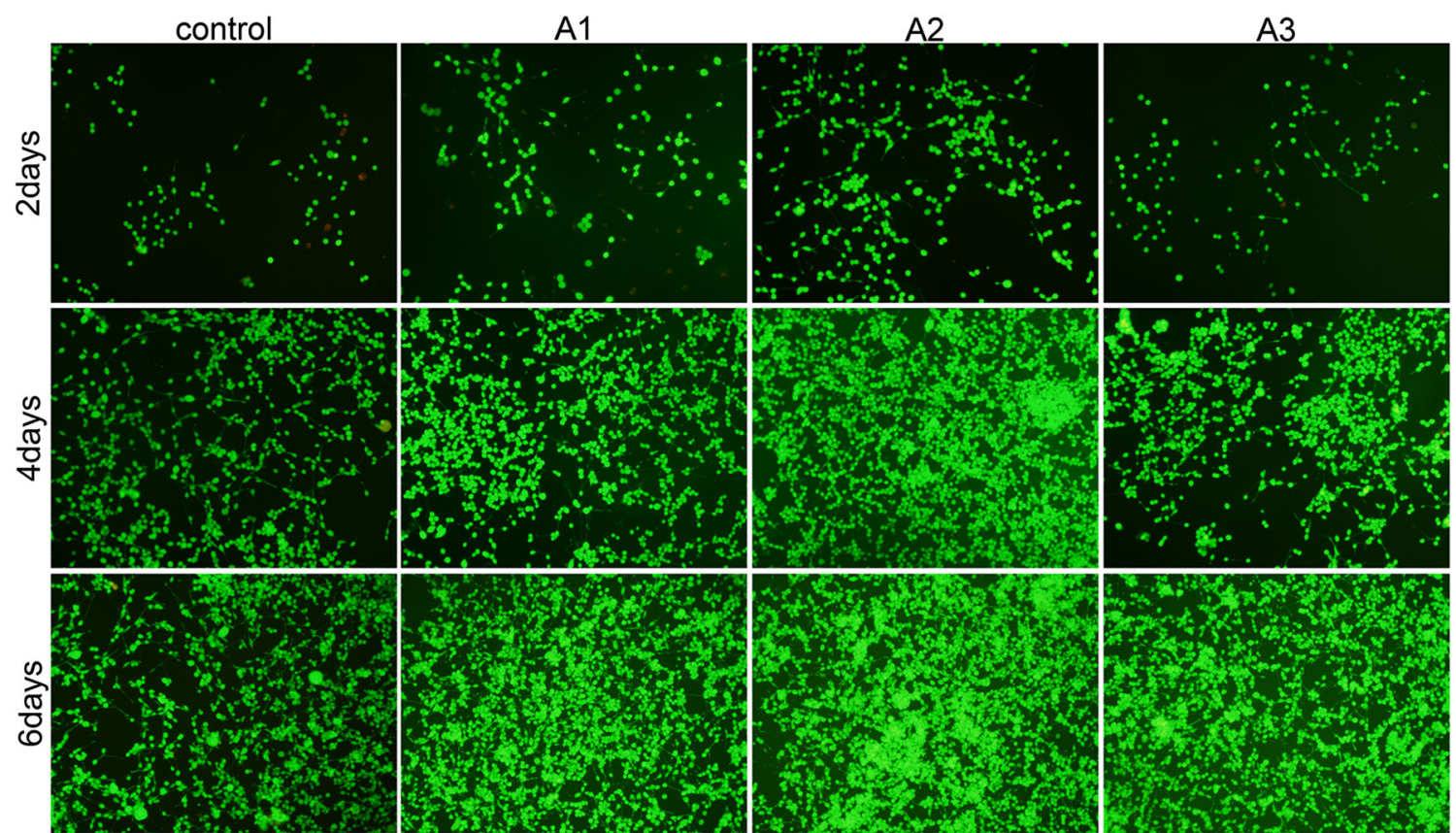

Fig. 5 Confocal laser scanning microscopy images showing the viability of RSC96 cells cultured in vitro with $0 \mu \mathrm{M}$ (control), $5 \mu \mathrm{M}$ (A1), $10 \mu \mathrm{M}$ (A2), and $20 \mu \mathrm{M}$ (A3) $\beta$-asarone for 2, 4, and $6 \mathrm{~d}$. Cell seeding density: $4 \times 10^{3} / \mathrm{mL}$ (original magnification $\times 100$ )

Publisher's note Springer Nature remains neutral with regard to jurisdictional claims in published maps and institutional affiliations. 